\title{
Ліквідація наслідків радіоактивного зараження на нових фрізичних принципах
}

\begin{abstract}
С.О. Дичко, В.В. Барбашин
${ }^{1}$ Східне регіональне управління Державної прикордонної служби України; (м. Харків, Україна), е-mail: sergejdu4ko@gmail.com; ORCID:0000-0002-7070-5941 ${ }^{2}$ Харківський національний університет міського господарства імені О.М. Бекетова (м. Харків, Україна), e-mail: barbachyn@ukr.net; ORCID: 0000-0003-3262-8305

Радіаційний вплив джерел іонізуючого випромінювання, які сьогодні широко застосовуються у світі, можна вважати одним із небезпечних техногенних факторів, якій може мати негативний вплив на людину та навколишнє середовище. Лазерний метод дезактивації базується на випаровуванні оксидних плівок під впливом випромінювання. Під дією випарювального механізму лазерне випромінювання повинно за час імпульсу нагріти верхній шар плівки до температури кипіння та випарити його. Даний метод є актуальним тому, що у світі зростають вимоги до екологічної безпеки, це дає можливість створення компактної, енергоефективної лазерної установки. На відміну від існуючих лазерних енергоефективних установок, детонаційна лазерна система надасть можливість суттєво впливати та швидко здійснювати дезактивацію забруднених поверхонь радіоактивними ізотопами за рахунок випаровування оксидних плівок під дією випромінювання. Детонаційні технології відносяться до критичних технологій, на основі яких можуть бути реалізовані пульсуючі детонаційні системи, наприклад, пульсуючі детонаційні двигуни, детонаційні лазери, магнітогідродинамічні генератори з детонаційним згоранням палива, системи ініціювання об'ємного вибуху, тощо. Впровадження цих систем на озброєнні та військовій техніці може суттєво змінити сореру їх застосування. Середня потужність лазера може досягати 100 кВт і вище. При цьому застосування суміші як джерела енергії, робить систему не тільки компактною, але і малою по масі у відношенні до існуючих подібних систем. Довжина хвилі за рахунок формування випромінювання в далекій інфрачервоній області становитиме 10,6 мкм.
\end{abstract}

Ключові слова: передіонізація, лазери, детонація, дезактивація, лазерне
випромінювання, напруга.

Постановка проблеми. Вимоги, що зростають у світі до екологічної безпеки, дають можливість створення компактної, енергоесрективної лазерної установки. На відміну від існуючих лазерних енергоефективних установок, детонаційна лазерна система надасть можливість суттєво впливати та швидко здійснювати дезактивацію забруднених поверхонь радіоактивними ізотопами за рахунок випарювання оксидних плівок під дією випромінювання. Детонаційні технології відносяться до критичних технологій, на основі яких можуть бути реалізовані пульсуючі детонаційні системи, наприклад, пульсуючі детонаційні двигуни, детонаційні лазери, магнітогідродинамічні генератори з детонаційним згоранням палива, системи ініціювання об'ємного вибуху. Впровадження цих систем на озброєнні та військовій техніці може суттєво змінити сфреру їх застосування. Середня потужність лазера може перевищувати 100 кВт і вище. При цьому, застосування вуглецевого палива, як джерела енергії, робить систему не тільки компактною, але і малою по масі у відношенні до існуючих подібних систем.
Довжина хвилі за рахунок формування випромінювання в далекій інфрачервоній області становитиме 10,6 мкм. Тобто, комбіновані силові установки забезпечать не тільки силовий привід і електричне енергозабезпечення машин. Це дозволить створити силові детонаційні установки з частотою періодичного ініціювання не менш, ніж 100 Гц, які будуть працювати на зрідженій суміші пропан-бутану з повітрям і незначним використання кисню.

Аналіз останніх досліджень і публікацій.

В роботі $[1,2]$ вказувалось, що у США, ЮАР та Росії розроблені та впроваджені методи лазерного поділу ізотопів. Широко застосовуються лазерні лідари для контролю за забрудненням середовища радіоактивними ізотопами. Деякі компанії США та Росії використовують лазерні системи у процесі утилізації обладнання АЕС.

У Росії з початку 90-х років у ДНЦ РФ "TPIHITI" почалось розроблення мобільних технологічних комплексів на базі потужних газорозрядних $\mathrm{CO}_{2}$-лазерів [3]. У кінці 90-х років були створені комплекси МЛТК-5 і МЛТК-50. Комплекс 
МЛТК-5 створений на основі безперервного $\mathrm{CO}_{2}-$ лазеру замкненого контуру з накачуванням самостійним розрядом із вихідною потужністю 5 кВТ, який базується на шасі автомобіля.

Комплекс МЛТК-50 був створений на основі імпульсно-періодичного електроіонізаційного $\mathrm{CO}_{2}$-лазера відкритого контуру з потужністю 50 кВт. Обладнання розміщувалось на двох автомобільних напівпричепах, вага дорівнювала 48 т.

Таблиця 1. Параметри роботи лазерних комплексів

\begin{tabular}{|c|c|c|c|c|}
\hline Установка & 产 & 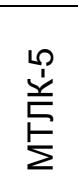 & 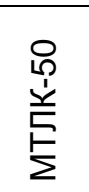 & $\begin{array}{l}\stackrel{ }{N} \\
\text { y. } \\
\stackrel{E}{E}\end{array}$ \\
\hline $\begin{array}{l}\text { Загальна вага } \\
\text { комплекту, т }\end{array}$ & 0,04 & 11 & 50 & $\begin{array}{l}2 \text { ко- } \\
\text { жен } \\
\text { блок }\end{array}$ \\
\hline $\begin{array}{l}\text { Відстань } \\
\text { об'єкта, м }\end{array}$ & $\begin{array}{l}\text { до } \\
1,5 \\
\end{array}$ & $\begin{array}{l}\text { до } \\
70\end{array}$ & 50 & 70 \\
\hline $\begin{array}{l}\text { Споживча по- } \\
\text { тужність, кВт }\end{array}$ & 3 & 150 & 750 & $\begin{array}{l}32 \text { ко- } \\
\text { жен } \\
\text { блок }\end{array}$ \\
\hline $\begin{array}{l}\text { Довжина хвилі, } \\
\text { мкм }\end{array}$ & 1,06 & 10,6 & 10,6 & 1,07 \\
\hline $\begin{array}{l}\text { Частота ініцію- } \\
\text { вання детона- } \\
\text { ції, Гц }\end{array}$ & 50 & 50 & 50 & 50 \\
\hline $\begin{array}{l}\text { Вихідна потуж- } \\
\text { ність, кВТ }\end{array}$ & - & $\begin{array}{r}0,5 \\
-5,0\end{array}$ & 50 & 8 \\
\hline
\end{tabular}

У США фрірмою AVLIS (Atomic Vapor Laser Isotope Separation) із 1970 до 1980 року розроблялись лазерні системи, які випарюють ізотопи [4]. Ця ідея відмерла внаслідок загальної кількості потужностей і скорочення арсеналу озброєння. За допомогою лазера можливо іонізувати атоми якого-небудь ізотопу. Суттєвий недолік полягає у переналаштуванні з одного ізотопу на інший.

Американським департаментом 3 енергії (DOE, US Department of Energy) було запропоновано для дезактивації ядерних установок використовувати високопотужні лазери [5]. У період із 1992 до 1996 року лабораторією Еймса в межах проекту Ames Laser Decontamination Project досягнуто результатів з розробки ексимерного KrF-лазеру потужністю 100 Вт (248 нм) і Nd-лазер YAG Q-switch (1064 нм), для вивчення переміщення радіоактивного оксиду по металевих поверхнях. Для розробки був запропонований прототип лазера Nd: YAG, який працює в короткому діапазоні, довжина його хвилі становила (1064 нм), за допомогою звичайних оптичних волокон. Інші проекти призначались для дезактивації бетону [6]. Нещодавно для розбирання ядерних установок був запропонований хімічний лазер 3 назвою COIL (Chemical Oxygen lodine Laser) [7].
У Франції починаючи з 1999 року проведено досліди з лазером Nd: YAG та ексімерним лазером [8]. Комісаріатом з атомної енергії був розроблений і випробуваний прототип LEXDIN на випадок дезактивації камери з оргскла. Дезактивація за допомогою ультрафіолетового лазера: прототип LEXDIN, CEA, 1996, в якому використовується XeCl-лазер і дзеркала для передавання лазерного пучка.

В Бразилії зростає інтерес до лазерної радіоактивної дезактивації металевих поверхонь. Основними перевагами в порівнянні з традиційними методами: підвищена безпека, зменшення вторинних відходів, зменшення обсягу відходів, прийнятна вартість. Основним механізмом очищення $\mathrm{CO}_{2}$-лазер лазерами є абляція [9].

В роботі [10] приводяться попередні резуль-

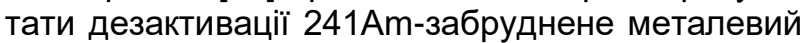
лом, отриманий при обробці радіоактивних блискавковідводів лазерної абляції. Наносекундний лазер Nd: YAG використовувався з енергією 300 мДж, залишаючи лише невелику кількість вторинних відходів, що підлягають обробці.

Про практичний метод значного скорочення обсягів забруднених відходів, які повинні зберігатися шляхом використання когерентного випромінювання, що випускається лазером, для видалення фіксованого радіоактивного забруднення тільки з поверхні металевих відходів, зазначено в роботі [11]. Одномодовий імпульсний волоконний лазер використовувався для видалення фіксованого забруднення з підкладки з нержавіючої сталі шляхом абляції.

Експериментальні результати дезактивації ексімерним лазером були отримані для різних радіонуклідів (Cs, Co, Eu i т.д.), осадження в різних умовах (фріксований або нефіксоване забруднення). Прототип лазерної дезактивації складається з XeCl-лазера, пучка волокон для передачі променя, оптичної системи та збірного осередку з фільтром для видалення віддалених частинок. Кім того, передбачений комп'ютерний контроль ефективності очищення і переміщення пучка [12].

В роботі [13] описано прототип лазерного очищення на основі процесу ексімерлазерної абляції. Цей прототип був випробуваний на ядерних установках. В основному він складається з ХеClлазера, пучка волокон для передачі променя, оптичних систем, осередки для збору з фільтром для видалення віддалених частинок, комп'ютерного контролю ефективності очищення і зміщення променя.

$\mathrm{CO}_{2}$ лазери мають низку суттєвих недоліків, а саме: високі енергоефективні вимоги до установки, великі масогабаритні показники за рахунок систем охолодження та турбокомпресорів, низька вихідна потужність і високі витрати на виготовлення. 
Детонаційне згоряння палива в детонаційних системах виключає потребу у використанні турбокомпресорів для накачування детонаційної труби з відповідним зменшенням енерговитрат.

Мета статті полягає у застосуванні для отримання лазерного випромінювання була запропонована у вигляді детонаційного лазеру, які показали високу ефективність, але конструкція була одноразовою [14].

На підставі зазначеного можна стверджувати, що актуальним $є$ проведення дослідження 3 розроблення пропозицій із створення компактної лазерної установки. Вона виключає потребу у використанні турбокомпресорів для накачування детонаційної труби, систем охолодження лазерних агрегатів, що відповідно зменшує енерговитрати.

Головна і невирішена на сьогодні проблема в практичній реалізації пульсуючих детонаційних систем пов'язана зі створенням енергоефективної системи періодичного ініціювання детонації.

\section{Виклад основного матеріалу}

На основі пульсуючих детонаційних систем, запропонований варіант реалізації детонаційного лазера. За рахунок детонаційного згоряння палива, використання для накачування енергії хімічних реакцій та через відсутність додаткової системи прокачування робочого середовища зменшуються масогабаритні показники системи, збільшується коефріцієнт корисної дії та підвищення робочої температури в середовищі.

Детонаційний лазер працює таким чином [15]. Детонаційна труба 1, що має відкритий отвір з одного боку, через систему клапанів 2 заповнюється воднево-кисневою сумішшю 3, здатною до детонації. Біля закритого торця труби за допомогою джерела розряду 4 здійснюється ініціювання детонації 5 у суміші 3. Поширення детонації 6 по суміші 3 призводить до "миттєвого" її згоряння (рис. 1).

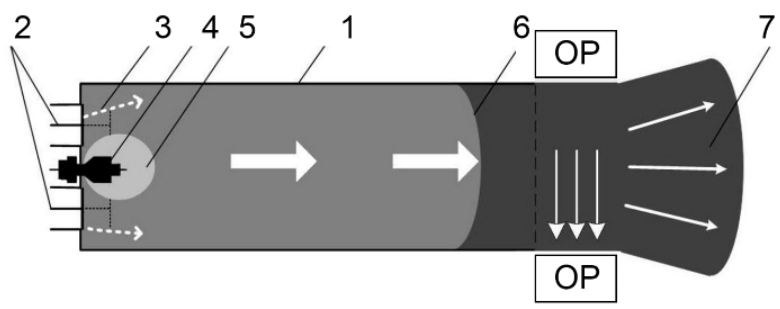

Рис. 1. Схема роботи детонаційного лазеру: $\mathrm{OP}$ - оптичний резонатор

Результатом детонаційного згоряння є зростання тиску та температури в продуктах хімічної реакції, серед яких наявні молекули діоксиду вуглецю СO2. Перепад тиску, що утворюється між продуктами детонації та зовнішнім середовищем, призводить до надзвукового розширення про- дуктів детонації із швидким охолодженням у зоні оптичного резонатора 7 (рис.1). Це створює умови для виникнення інверсії насиченості в коливально збуджених молекулах СО2 та забезпечує виникнення лазерного випромінювання.

За великої частоти ініціювання детонації стає прийнятним обмеження витрат енергії розряду на ініціювання детонації. Так, за витрати енергії на один імпульс ініціювання близько 500 Дж сумарна потужність системи ініціювання детонації за частоти 100 Гц становить 50 кВт. Це робить детонаційні лазери енерговитратними з виникненням технічних проблем щодо енергозабезпечення. Визначено, що енергія імпульсу ініціювання не повинна перевищувати 50 Дж, що можна досягнути, якщо ККД потужних іскрових розрядів не перевищує $1 \%$. Створення та застосування детонаційного лазера з параметрами (табл. 2) дозволяє проводити дезактивацію радіоактивно забруднених об'єктів. Часткове охолодження системи відбувається за рахунок періодичного режиму роботи з заповнюванням труби холодною сумішшю, виключається потреба у використанні великих систем охолодження.

Таблиця 2. Параметри роботи детонаційного лазера

\begin{tabular}{|l|c|}
\hline \multicolumn{1}{|c|}{ Параметри } & Значення \\
\hline $\begin{array}{l}\text { Енергія на поодиноке ініціювання } \\
\text { детонації, Дж }\end{array}$ & 50 \\
\hline Частота ініціювання детонації, Гц & 50 \\
\hline Споживана потужність, кВт & 4 \\
\hline Вихідна потужність, кВт & 50 \\
\hline Робоча суміш & $\begin{array}{c}\text { пропан } \\
\text {-кисень }\end{array}$ \\
\hline Довжина хвилі випромінювання, мкм & 10,6 \\
\hline
\end{tabular}

Температура в продуктах детонації може перевищувати $3000 \mathrm{~K}$, що відрізняться від газодинамічних $\mathrm{CO} 2$-лазерів, де робоча температура не перевищує 1400 К, або хімічних лазерів, де температура сягає 1500-1800 К. У разі підвищення температури зростає потужність [16].

Гонка озброєнь між державами, недосконалість технології залишили нам у спадок забруднену територію, що змушує нас задуматись над тим, яким чином очистити територію від радіоактивного забруднення.

У військовій сфрері сучасні погляди на ведення бойових дій у воєнних конфліктах різного ступеня інтенсивності не передбачають використання ядерної зброї. Разом із цим можливе широке застосування високоточної зброї. Перш за все високоточна зброя буде уражати адміністративні центри, пункти керування, систему ППО, підприємства ядерної енергетики. У результаті зруйнувань останніх, утворюються зони зараження, що за своїми масштабами аналогічні зонам зараження в разі застосування зброї масового ураження. 


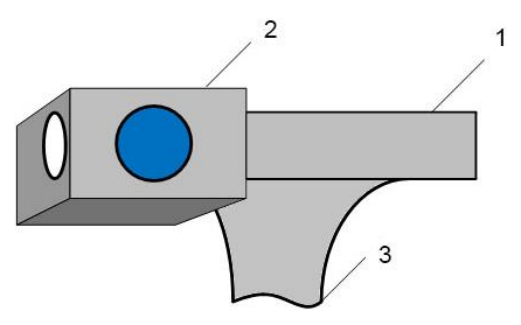

Рис. 2. Загальний вигляд детонаційної лазерної установки: 1 - кріплення; 2 - детонаційна

труба; 3 - зона оптичного резонатору

Для вирішення цих завдань військами РХБ захисту застосовуються підрозділи й частини РХБ захисту, які в мирний і військовий час виконують завдання. В разі виникнення загрози радіаційного зараження, проведення у тому числі й дезактивацію озброєння, техніки та місцевості. Але в сучасних умовах, наявні засоби не дозволяють повною мірою проводити дезактивацію. Повна дезактивація фрізико-хімічним способом проводиться шляхом змивання радіоактивних речовин водними розчинами миючих засобів, водою і порошками СФ-2У, за допомогою брандспойтів машини АРC 14 (APC 15), але даний спосіб та наявні засоби не дозволяють повністю очистити від радіоактивного зараження, а лише частково змити верхній шар.

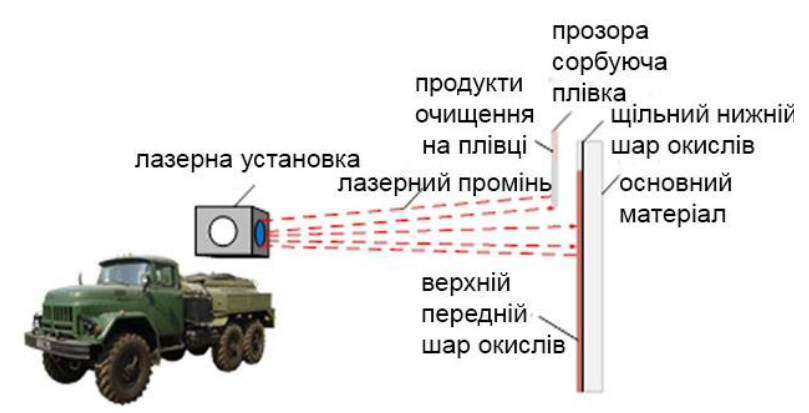

Рис. 3. Застосування лазерних систем у військовій сфрері

\section{Висновки}

1. Встановлено, що наявні лазерні комплекси мають ряд суттєвих недоліків, а саме: велику вагу установки; високі витрати енергії; низький коефіцієнт корисної дії; великі затрати на фінансування, що є головним чинником для створення компактної установки за своїми масо-габаритними параметрами, вирішенням питання енергоефективності та збільшенням ККД за рахунок більш високої температури.

2. Застосування та впровадження лазерних технологій може надати значні переваги порівняно з існуючими способами та методами проведення дезактивації. Лазерна обробка надає можливість вирішити проблему багаторазового змен- шення або повного зняття радіоактивного зараження техніки та споруд.

3. Можливість підвищувати температуру до 3000 К, що може нейтралізувати радіоактивне забруднення, шляхом зняття шару матеріалу від 0,1 до 20 мм.

\section{Література:}

1. Галак О. В. Застосування детонаційних $\mathrm{CO}_{2}$-лазерів для дезактивації // Збірник наукових праць ХУПС, 2014.- №1 (38). - С. 241 - 245.

2. Вейко В. П. Лазерная дезактивация металлических поверхностей // Оптический журнал. 2007. - Т. 74. № 8. - С. 33.

3. Блохин О.А. Мобильный лазерный комплекс для аварийно восстановительных работ в газовой промышленности // Газовая промышленность. 2001. С. 33-34.4. Белозеров И.В. Религиозная политика: дис. ... канд. ист. наук: 07.00.02; защищена 22.01.02; утв. 15.07.02 / Белозеров Иван Валентинович. - К., 2002. - 215 с.

4. Stem R. C. Atomic Vapor Laser Isotope Separation // First International Laser Science Conference. 1985. № 8. S. 42.

5. Gas generating system for chemical lasers: пат. 5,624,654 USA. № US5624654 А. МПК 08/647,610; заявл. 13.05.1996; опубл. 29.04.1997.

6. Савина М. Эффективность удаления бетона с помощью импульсного Nd: YAG-лазера // J. Laser Appl. 2000. - № 12 (5). - C. 200 - 204.

7. William P. Cutting Performance of a Chemical Oxygen-lodine Laser // Proc. of SPIE. 1998. Vol. 3268. P.130.

8. Способ дезактивации поверхности, расположенной в зоне радиоактивного загрязнения ядерной установки: пат. 5011049/25 Франция. № 2084978; заявл. 24.03.1992; опубл. 20.07.1997, Бюл. № 16.

9. Miljanic S. S. An attemp to use a pulsed $\mathrm{CO} 2$ laser for decontamination of radioactive metal surfaces // Journal of the Serbian Chemical Society. 2000. 65 (5-6). P. 445 - 450.

10. Potiens A. J. Laser decontamination of the radioactive lightning rods // Journal Radiation Physics and Chemistry. 2014. V. 95. P. 188 - 190.

11. Kumar A. Laser assisted removal of fixed radioactive contamination from metallic substrate // Journal Nuclear Engineering and Design. 2017. V. 320. P. 183 - 186.

12. Delaporte $\mathrm{Ph}$. Radioactive oxide removal by $\mathrm{XeCl}$ laser // Applied Surface Science. 2002. V. 197 - 198. P. 826 - 830.

13. Delaporte Ph. Dry excimer laser cleaning applied to nuclear decontamination // Applied Surface Science. 2003. V. 208 - 209. P. 298 - 305.

14. Джиджоев М. С. Детонационный газоденамический лазер // Письма в ЖЕТФ. 1971. Т. 13.- С.73 - 76. 
15. Галак О. В. Напрями розвитку лазерної зброї вчора, сьогодні, завтра // Системи озброєння і військова техніка. 2013. № 4 (13). C. $123-130$.

16. Галак О. В. Перспективи розвитку пульсуючих детонаційних систем. Труднощі їх реалізації // Системи озброєння і військова техніка, 2014. № 2 (38). С. 73 - 76.

\section{References:}

1. Halak O. V. Zastosuvannya detonatsiynykh SO2-lazeriv dlya dezaktyvatsiyi // Zbirnyk naukovykh prats' KhUPS. 2014. \#1 (38). S. 241 - 245.

2. Veyko V. P. Lazernaya dezaktivatsiya metallicheskikh poverkhnostey // Opticheskiy zhurnal. 2007. T. 74. № 8. S. 33.

3. Blokhin O. A. Mobil'nyy lazernyy kompleks dlya avariyno vosstanovitel'nykh rabot $v$ gazovoy promyshlennosti // Gazovaya promyshlennost'. 2001. S. 33 - 34.

4. Stem, R., \& Pdsner, J. (1985) Atomic Vapor Laser Isotope Separation. First International Laser Science Conference, 8, 42.

5. Gas generating system for chemical lasers: пат. 5,624,654 USA. № US5624654 A. МПК 08/647,610; заявл. 13.05.1996; опубл. 29.04.1997.

6. Savina M. Effektivnost' udaleniya betona s pomoshch'yu impul'snogo Nd: YAG-lazera // J. Laser Appl. 2000. № 12 (5). S. 200 - 204.

7. William, P., James, L., \& Rothenflue, A. (1998). Cutting Performance of a Chemical Oxygenlodine Laser // Proc. of SPIE, 3268, 130.

8. Sposob dezaktivatsii poverkhnosti, raspolozhennoy $v$ zone radioaktivnogo zagryazneniya yadernoy ustanovki: pat. 5011049/25 Frantsiya. № 2084978; zayavl. 24.03.1992; opubl. 20.07.1997, Byul. № 16 .
9. Miljanic, S., Stjepanovic, N., \& Trtica, S. (2000). An attemp to use a pulsed CO2 laser for decontamination of radioactive metal surfaces. Journal of the Serbian Chemical Society, 65(5-6), 445 - 450.

10. Potiens, A., Dellamano, J., Vicente, R., Raele, M., Wetter, N., \& Landulfo, E. (2014). Laser decontamination of the radioactive lightning rods. Journal Radiation Physics and Chemistry, 95, 188 - 190.

11. Kumar, A., Prakash, T., Prasad, M., Shail, S., Bhatt, R., Beherea, P., \& Biswasb, D. (2017). Laser assisted removal of fixed radioactive contamination from metallic substrate. Journal Nuclear Engineering and Design, 320, 183 - 186.

12. Delaportea, Ph., Gastauda, M., Marineb, W., Sentisa, M., Uteza, O., Thouvenotc, P., Alcarazc, J., Le Samedy, J., \& Blind, D. (2002). Radioactive oxide removal by $\mathrm{XeCl}$ laser. Applied Surface Science, 197 - 198, 826 - 830.

13. Delaporte, Ph., Gastaud, M., Marine, W., Sentis, M., Uteza, O., Thouvenot, P., Alcaraz, J., Le Samedy, J., \& Blin, D. (2003). Dry excimer laser cleaning applied to nuclear decontamination. Applied Surface Science, 208 - 209, 298 - 305.

14. Dzhidzhoev M.S. Detonatsionnyy gazodenamicheskiy lazer // Pis'ma v ZhETF. 1971. T. 13. S.73 - 76 .

15. Halak O.V. Napryamy rozvytku lazernoyi zbroyi vchora, s'ohodni, zavtra // Cystemy ozbroyennya i viys'kova tekhnika. 2013. \# 4 (13). S. $123-130$.

16. Halak O.V. Perspektyvy rozvytku pul'suyuchykh detonatsiynykh system. Trudnoshchi yikh realizatsiyi // Cystemy ozbroyennya i viys'kova tekhnika. 2014. \# 2 (38). S. 73 - 76.

\title{
Аннотация
}

\section{Ликвидация последствий радиоактивного заражения на новых физических принципах}

\author{
С.А. Дычко, В.В. Барбашин
}

Радиационное воздействие источников ионизирующего излучения, которые сегодня широко применяются в мире, можно считать одним из опасных техногенных факторов, которой может оказать негативное влияние на человека и окружающую среду. Лазерный метод дезактивации базируется на испарении оксидных пленок под воздействием излучения. Под действием испарительного механизма лазерное излучение должно за время импульса нагреть верхний слой пленки до температуры кипения и выпарить его. Данный метод актуален потому, что в мире растут требования к экологической безопасности, это дает возможность создания компактной, энергоэффективной лазерной установки. В отличие от существующих лазерных энергоэффективных установок, детонационная лазерная система позволит существенно влиять и быстро осуществлять дезактивацию загрязненных поверхностей радиоактивными изотопами за счет испарения оксидных пленок под действием излучения. Детонационные технологии относятся к критическим технологиям, на основе которых могут быть реализованы пульсирующие детонационные системы, например, пульсирующие детонационные двигатели, детонационные лазеры, магнитогидродинамические генераторы с детонационное сгорание топлива, системы иници- 
ирования объемного взрыва, и тому подобное. Внедрение этих систем на вооружении и военной технике может существенно изменить сфреру их применения. Средняя мощность лазера может достигать 100 кВт и выше. При этом применение смеси как источники энергии, делает систему не только компактной, но и малым по массе в отношении существующих подобных систем. Длина волны за счет формирования излучения в дальней инфракрасной области составит 10,6 мкм.

Ключевые слова: лазеры, детонация, дезактивация, лазерное излучение, напряжение.

\section{Abstract}

\section{Elimination of the consequences of radioactive infection on new physical principles}

\section{S.A. Dycko, V.V. Barbashyn}

Radiation exposure to sources of ionizing radiation, which are widely used in the world today, can be considered one of the dangerous man-made factors, which can have a negative impact on humans and the environment. The laser decontamination method is based on the evaporation of oxide films under the influence of radiation. With the evaporation mechanism, laser radiation should heat the upper layer of the film to the boiling point during the pulse and evaporate it. It is relevant because of the growing environmental requirements in the world, which makes it possible to create a compact, energy-efficient laser installation. Unlike existing energy-efficient laser units, the detonation laser system will significantly affect and quickly decontaminate radioactive surfaces due to the evaporation of oxide films under the influence of radiation. Detonation technologies are critical and can be used for pulse detonation systems, such as pulse detonation engines, detonation lasers, magnetohydrodynamic generators with detonation combustion of fuel, volume explosion initiation systems. The introduction of these systems in armaments and military equipment can substantially change the scope of their application. The average laser power can exceed $100 \mathrm{~kW}$ and above. At the same time, the use of the mixture as a power source makes the system not only compact, but also light in weight with respect to the existing similar systems. The wavelength will be $10.6 \mu \mathrm{m}$ due to radiation in the far infrared region.

Keywords: lasers, detonation, decontamination, laser radiation, voltage.

Бібліографічне посилання/ Bibliography citation: Harvard

Dycko, S. A. and Barbashyn, V. V. (2020) 'Elimination of the consequences of radioactive infection on new physical principles', Engineering of nature management, (1(15)), pp. 125 - 130.

Подано до редакції / Received: 09.01.2020 